\title{
Isolation of Intermediate in Biosynthesis of Eritadenine from Adenine
}

A new hypocholesterolemic substance, eritadenine ${ }^{1}$, was isolated from an edible mushroom 'Shiitake' (Lentinus edodes), and its chemical structure was confirmed in our laboratory ${ }^{2}$ to be 4 -(6-amino-9H-purine-9-yl)-2,3dihydroxybutyric acid (II). Eritadenine is the first example of the adenine 9-substituted with hydroxy acid in natural products and its biosynthesis is of special interest in our investigation. In view of the structural relationship of eritadenine to adenine, the latter substance is presumed to be a possible precursor of eritadenine. To prove this hypothesis, adenine-8-C $\mathrm{C}^{\mathbf{1 4}}$ was infused into a Shiitake. From the distribution of $\mathrm{C}^{14}$ it was suggested that eritadenine was synthesized from adenine via the intermediate, substance A. This intermediate was obtained as<smiles>Nc1ncnc2c1ncn2CCC(O)C(=O)O</smiles><smiles>Nc1ncnc2c1ncn2CC(O)C(O)C(=O)O</smiles>

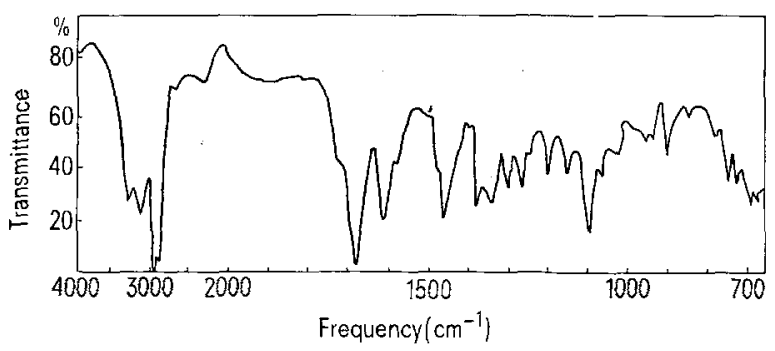

IR-spectrum of substance A (in Nujol).

Radioactivities of fractions isolated by an amino acid analyzer ${ }^{\mathrm{a}}$

\begin{tabular}{|c|c|c|c|}
\hline \multirow{3}{*}{ Peaks } & \multirow{3}{*}{ Effluent (ml) } & \multicolumn{2}{|c|}{ Radioactivity $(\mathrm{cpm} \times 1000)$} \\
\hline & & \multicolumn{2}{|c|}{ Time of culture after infusion } \\
\hline & & $6 \mathrm{~h}$ & $24 \mathrm{~h}$ \\
\hline Eritadenine & 178-185 & 39.8 & 64.6 \\
\hline Substance A & $208-212$ & 52.7 & 30.5 \\
\hline $\mathrm{B}$ & $245-252$ & 29.9 & 20.8 \\
\hline Adenine & $361-375$ & 33.7 & 18.8 \\
\hline
\end{tabular}

Adenine-8- $\mathrm{C}^{14}$ (22 $\mathrm{mCi} / \mathrm{m} \mathrm{mol}$ ) was purchased from Daiichi Pure Chemical Company (Japan). a The column contained $0.9 \times 50 \mathrm{~cm}$ of resin (Amberlite CG-120). It was operated at $50^{\circ}$ using buffer flow rate of $30 \mathrm{ml} / \mathrm{h}$. The buffer change ( $\mathrm{PH} 3.25$ to 4.25 ) was made after $2.5 \mathrm{~h}$, and the change to pH 5.28 after $5 \mathrm{~h}$. crystalline powder and identified as 4-(6-amino-9H-purine-9-yl)-3-hydroxybutyric acid (I). SAITo et al. ${ }^{3}$ and ToKITA et al. ${ }^{4}$ isolated the same substance, but its biological role in Shiitake has not been discussed.

In the cap of growing Shiitake on trunks of 'Kunugi' (Quercus acutissima), a small hole was made with corkborer. $20 \mu \mathrm{Ci}$ of adenine-8-C ${ }^{14}$ dissolved in a small volume of $0.9 \%$ sodium chloride solution was gradually infused into the hole and then the hole was blocked up. The Shiitake was harvested at 6 and $24 \mathrm{~h}$ after infusion and extracted with $80 \%$ ethanol. The extract was fractionated on an amino acid analyzer, Hitachi KLA-3, specially equipped UV-detector. The effluent peaks having absorption at $254 \mathrm{~nm}$ were collected. Radioactivity of the respective peaks was determined on a Beckman liquid scintillation spectrometer.

In the Table are shown the radioactivities of major peaks. The most radioactive substance $\mathrm{A}$ in $6 \mathrm{~h}$ sample was eluted in the fraction between 208 and $212 \mathrm{ml}$. At $24 \mathrm{~h}$ after infusion, the radioactivity of substance $\mathrm{A}$ decreased and that of eritadenine increased. Therefore, substance A could be expected to be one of the intermediates in the sequence of the biosynthesis of eritadenine from adenine.

Isolation of the substance from dried Shiitake was made by preparative amino acid analyzer in a manner similar to that previously employed for the isolation of eritadenine ${ }^{2}$. Approximately $70 \mathrm{mg}$ were obtained from $2 \mathrm{~kg}$ of dried Shiitake, Anal. C, 45.20; H, 4.62; N, 29.25. Calcd, for $\mathrm{C}_{9} \mathrm{H}_{11} \mathrm{O}_{3} \mathrm{~N}_{5}: \mathrm{C}, 45.57 ; \mathrm{H}, 4.67 ; \mathrm{N}, 29.53, \mathrm{mp}$ $271-5^{\circ}$ (dec.); $[\alpha]_{\mathrm{D}}^{20}+17.5^{\circ}$ (C, 0.5 in $0.1 \mathrm{~N} \mathrm{NaOH}$ ). The substance exhibits a characteristic UV-absorption of 9-substituted adenine $\lambda_{\text {max }}^{0.1 \mathrm{~N} \mathrm{HCl}} 261 \mathrm{~nm}(\varepsilon, 12824), \lambda_{\text {max }}^{0.1 \mathrm{~N} \mathrm{NaOH}}$ $262 \mathrm{~nm}(\varepsilon, 14038)$. The IR-spectrum is shown in the Figure. The NMR-spectrum of the sodium salt had the following signals: (60 MHz in $\left.\mathrm{D}_{2} \mathrm{O}\right)$ multiplet at $\delta$ (ppm) 2.5 (2 protons), broad triplet at 4.3 ( 1 proton), triplet at 4.5 ( 2 protons), and singlet at 8.3 ( 2 protons). On the basis of these data, the structure of substance A was proposed as 4-(6-amino-9H-purine-9-yl)-3-hydroxybutyric acid.

Zusammenfassung. Zur Biosynthese von Eritadenin in einem Speisepilz "Shiitake» wurde 4-(6-amino-9H-purine9-yl)-3-hydroxybuttersäure als ein Zwischenprodukt isoliert und identifiziert.

\section{H. Itoh, T. Morimoto, K. Kawashima and I. Chrbata}

Research Laboratory of Applied Biochemistry, Tanabe Seiyaku Co., Ltd., Kashima-cho, Higashiyodogawa-ku, Osaka (Japan), 3 August 1972.

1 The trivial name 'lentinacin' was used in the previous paper ${ }^{2}$.

2 I. Chibata, K. Oxumura, S. Takeyama and K. Kotera, Experientia 25, 1237 (1969).

3 Y. Saito, M. Hashimoto, H. Seki and T. Kamiya, Tetrahedron Lett. $1970,4863$.

4 F. Tokita, N. Shibukawa, T. Yasumoto and T. Kaneda, J. Japan Soc. Food Nutr. 24, 92 (1971).

\section{Effects of Fruit on Ribulosediphosphate Carboxylase Activity in Citrus madurensis Leaves}

Previous measurements of photosynthetic rates of Citrus madurensis Loureiro (Tanaka, 1954) cuttings showed intensified $\mathrm{CO}_{2}$-uptake in fruiting as compared with non-fruiting plants ${ }^{1}$, and other workers have reported stimulatory effects of various 'metabolic sinks' on $\mathrm{CO}_{2}$-uptake ${ }^{2,3}$. WAREING et al. ${ }^{2}$, also suggested that hormones derived from these sinks may stimulate formation of carboxylating enzymes in neighbouring leaves. In 